\title{
Fucosyl GM1 Antibody
}

National Cancer Institute

\section{Source}

National Cancer Institute. Fucosyl GM1 Antibody. NCI Thesaurus. Code C118195.

Any immunoglobulin that recognizes the fucosyl form of gang lioside GM1. 